\title{
Jean-Joseph Rabearivelo, Charles Maurras and Colonial Madagascar
}

Jean-Joseph Rabearivelo (1903-1937) is widely considered to be the first major writer of la francophonie. This Malagasy author, who taught himself French yet never set foot outside Antananarivo, is featured in Léopold Senghor's ground-breaking and canonical Anthologie de la nouvelle poésie nègre et malgache de langue française, and, even in his brief lifetime, was celebrated as Madagascar's premier French language writer. His suicide at the age of thirtyfour was later transformed into an anti-colonial gesture, beginning with his friend Robert Boudry's book Jean-Joseph Rabearivelo et la mort, published by Présence africaine in 1958. However, this posthumous recuperation of Rabearivelo involves suppression of the complexity of his politics and especially his notorious and outspoken support for Charles Maurras and Action française. The recent publication of Rabearivelo's journal, Les Calepins bleus, has offered new insights into his politics, but, among critics, only Martin Steins, in his controversial (and never published) thesis 'Les Origines et les antécédents de la négritude senghorienne', makes serious mention of Rabearivelo's far right affinities, as part of his wider investigation into Senghor's own 'reactionary' ideological roots. The political ideas of Rabearivelo therefore deserve more attention, in order to shed light on his literary work and ambiguous position in colonial Madagascar, but also on another neglected subject: the attitude of Action française towards the French Empire and colonialism in general.

\section{Jean-Joseph Rabearivelo and Colonial Madagascar}

Born in 1903, Jean-Joseph Rabearivelo was, on his mother's side, from a royal line, the Zandralambos, who, since the end of the eighteenth century, had been marginalised within the Hova class ruling Madagascar from the highlands of Imerina (or Emyrne). In 1896, this social decline was compounded by General Gallieni's abolition of slavery. The fallen aristocrat Rabearivelo therefore began his life without any privileges or fortune. An illegitimate child, he was taken into the care of his paternal uncle and began studies at catholic institutions, but quickly rejected religious indoctrination, leaving school definitively at the age of just thirteen. Rabearivelo earned his living from various small jobs: secretary and interpreter for a chef de district, courier, lace-designer then employee of the Cercle de l'Union. This latter job marked a turning-point: Rabearivelo was responsible for the Cercle's library, which allowed him to develop his burgeoning passion for French language and culture. In 1920, he frequented writer Samuel Jefatra's literary circle, which brought together 
medical students interested in assimilating Malagasies to western civilisation. Having consolidated, if not perfected, his knowledge of French, Rabearivelo devoted himself to literature, contributing articles, poems and short stories to Le Journal de Madagascar francomalgache and other reviews. Already in 1922, he was recognised by his peers as leader of an avant-garde called 'la phalange Rabearivelo'. In 1924, he published his first poetry collection in French , La Coupe de Cendres. It was also around this time that he found a steady job as copy editor at the Imprimerie de l'Imerina, which he would keep until his death.

The launch of Rabearivelo's literary career coincided with a period of considerable political and cultural effervescence in colonial Madagascar. 1920 had seen the return from exile of surviving members of the VVS, a secret society which had challenged French rule during the First World War. They had Rabearivelo's sympathy : in an unpublished text dated September 9 1925, the young poet called for not just an amnesty, but a complete revision of the VVS members' trial. Indeed, at this time, he was, privately at least, virulent in his criticisms of colonialism. In another unpublished text from this time, he denounced the Franco-Spanish war in the Rif: 'La guerre du Maroc est une honte. La guerre du Maroc est un désastre... Je n'arrive pas à excuser l'Occident, lequel, sous prétexte de civiliser, veut s'ériger en maître sur une terre après en avoir tué les propriétaires naturels ou, au moins, acheté à vil prix la conscience'. This 'esprit de lucre' had been a motivating factor in France's conquest of his homeland : 'Je me rappelle tous les actes honteux qui entachent de sang et de crimes la gloire et l'horreur (Mon Dieu!!!) dont se targue l'œuvre française à Madagascar, et qu'on lira demain dans mon Aube rouge'. He concluded : 'Nous te plaignons, nous sommes plus humains que toi, nous qu'ont nourris tes encyclopédies, et qui avons emprunté de tes lumières... Relève-toi, Occident. Marchons vers la Civilisation' (Fonds Rabearivelo, n.d.).

L'Aube rouge was his first novel in French. Inspired by René Maran, author of Batouala, veritable roman nègre and first coloured man to win the Prix Goncourt (in 1921), Rabearivelo aimed to tell the true story of the French conquest of Madagascar. In his preface, he wrote: 'Ignorant que chez les Hova, même sans livre, l'histoire se perpétue et se transmet de génération en génération par la voie des veillées, les politiques, influençant les historiens, ont donné une idée et une image très inexactes de la vie d'hier de ce people' (2012, p. 811). These oral accounts were, he maintained, of great use : 'Ils font savoir que les Hova, se croyant dans leur droit, ne se laissèrent pas faire et résistèrent vaillamment. Ils font savoir aussi que les Français ne réussirent pas d'un coup à écraser l'ennemi' (2012, p. 811). He ended by denouncing the humanitarian blindness of 'les politiques' : 
Qui ne flatte pas leur bassesse, ne favorise plus leur esprit de lucre et de matière celui-là est tout désigné à leur implacable persécution. Pour avoir réprimé ce danger, Mahatma Gandhi a connu la prison anglaise, Marcus Garvey pâtit en Amérique ; et Jean Ralaimongo souffre encore, à l'heure où j'écris, dans un cachot de Madagascar... Cette barbarie en plein XXème siècle, il faut la civiliser. (2012, p. 812)

L'Aube rouge gives literary form to this critique of colonialism. In 1895, the victorious French impose their will through the execution of innocent victims, most notably the poet and politician, Rainandriamampandry. Blood stains the new sun rising above Madagascar. That said, as Serge Meitinger points out, 'il reste clair que par cette image, un hommage implicite est rendu au rayonnement français; il n'a eu que le tort de s'assurer le pouvoir par une injuste violence' $(2012,804)$. As we have seen, Rabearivelo criticised the West for departing from its enlightened roots ; it was together that coloniser and colonised would rediscover and rebuild 'civilisation'.

\section{Rabearivelo and Maurras}

The preface to L'Aube rouge - which was not published until 1998 - is dated 'de l'an du Grand Roi'. Rabearivelo is haunted by the fall of the Hova dynasty and the loss of his own aristocratic status. In a poem of Volumes, published in 1928, he wrote : 'Quant à moi, fils des Rois d'une époque abolie,/reposant au rebord d'un tombeau qu'on oublie,/je chante d'une voix qui n'est pas de mes morts' $(2012,1644)$. Politically, Rabearivelo was not attracted by socialism and communism but rather by the ideas of Charles Maurras and Action française : anti-republican, anti-parliamentarian, anti-semitic, élitist and, above all, monarchist (1937b). The pages of his journal Les Calepins bleus from before 1933 were destroyed by the author, but a poem in Volumes, 'Au soleil estival', is dedicated to Charles Maurras, indicating an early adherence to the royalist movement. The poem expresses the classical Maurrassian theme of lost royal grandeur:

Insensible à l'averse et tout à sa pensée,

Etreignant du regard sa jeune fiancée,

L'enfant de nos amours latentes attendra 
Que d'Imanga, colline anciennement royale,

Vienne nous entourer l'âme immémoriale

De l'orgueil de l'Emyrne et du passé des Rois. $(2012,281)$

It was also in 1928 that Rabearivelo claimed to have been provoked by 'un jeune lettré indigène' who had questioned his aristocratic credentials. In response, he threw himself into the study of Malagasy history and culture in order to trace a royal genealogy in which he had his own place, notably in papers given to the Académie malgache. At the same time, there was a traditionalist turn in Rabearivelo's literary work, which moved away from a 'première manière' heavily influenced by French poetry, notably that of Pierre Camo, a magistrate in the colony. With other Malagasy intellectuals, he campaigned for a new literature rooted in traditional prosody as well as open to western influence. In the manifesto, 'Hitady ny very' ('A la recherché des valeurs perdues'), published in Ny Fandrosoam-baovo in 1932, its authors bemoaned the literary mimicry which had followed the arrival of the French: 'Trop pressés de changer de coiffure, nous ne nous étions même pas demandé si les nouveaux modèles convenait à la musique de notre langue, ou non, s'ils allaient lui faire du bien ou au contraire la détruire' (2012, p. 1285). Foreign imports would not be rejected, but rather used in the interests of renewal: 'Nous allons nous en servir comme d'un fusil, c'est par la poésie étrangère que nous allons la chercher et la rétablir... Si vous laissez vos oreilles retrouver leur état naturel, nous sommes convaincus, que vous retrouverez ce qui a été perdu' (2012, p. 1285). Inspired by this Franco-Malagasy dialogue of forms, Rabearivelo would produce his most distinctive and memorable works, Presque-songes and Traduit de la Nuit, while both writing and translating into Malagasy. Thanks to this literary renaissance, in 1934, the manifesto's authors could proclaim that 'les valeurs perdues ont été retrouvées' (2012, p. 1302).

This public demand for a return to lost values and cultural traditions could, of course, be interpreted as an expression of Malagasy nationalism. It is not surprising that Nancy Cunard approached Rabearivelo to contribute a text on Madagascar for the anthology Negro, published in 1934. This text, 'Coup d'œil sur le passé de Madagascar', translated by Samuel Beckett and placed beside a polemical article by communists Georges Citerne and Francis Jourdain on 'French Imperialism at work in Madagascar', recounted 'le crépuscule mouvementé et tragique que celui de l'Imerina' (2012, p. 1626) and reached a conclusion close to that of L'Aube rouge: 'Le royaume hova avait vécu, après avoir eu 25 souverains. Cela avait coûté plusieurs milliers à la France. Mais c'est son affaire. Nous, nous savons que 
nous avons eu plusieurs milliers de victimes civiles. Nos vieux et nos vieilles en parlent surtout du sage Rainandriamampandry - les yeux embués' (2012, p. 1626).

However, it is evident that Rabearivelo's position on colonial rule was not as radical as other contributors to the anthology. In a letter to Nancy Cunard on the present and future of Madagascar, dated 29 September 1932, he wrote:

Les dés sont jetés, ma chère amie; les faits sont accomplis : il y aura bientôt 40 ans que, le sort des armes nous ayant été adverses, Madagascar fait partie de la France. Mais qui s'en plaint? Ce ne sont pas les vieux : ils comparent les deux régimes et préfèrent le nouveau. Ce ne sont pas non plus les jeunes qui doivent tout à leur seconde patrie. (2012, p. 1638)

Rabearivelo therefore contrasted Madagascar with other countries benighted by racism :

On ignore ici, par exemple, et le lynchage qui décime les Aframéricains et l'ostracisme outrageant dont pâtissent les Nègres de l'Union Sud-Africaine. Il y a bien une poignée de mécontents qui prétendent le contraire, mais ils ne turent prétexte que de quelques petites misères inhérentes à la vie même. Comme si le monde avait cessé d'être le monde et qu'il n'y eût plus que des hommes parfaits. (2012, p. 1636)

The difficult days of pacification were now far behind the Malagasies. Rabearivelo did not mention the dictatorial powers of the administration, the disenfranchisement of the indigènes and the widespread recourse to forced labour, notably through the Service de la Main d'Oeuvre des Travaux d'Intérêt Général (SMOTIG), features of colonial rule which, as Jean Fremigacci (2014) has shown, were very much a continuation of the Ancien Régime. Instead, the poet expressed his fear that the 'poison' of politics would come and disrupt the harmony between coloniser and colonised. If this fear became reality, he concluded, 'je me ferais naturaliser français... Dans cette langue qui n'est pas mienne... j'aurais alors l'occasion de vous dire, devant tous nos amis de couleur, de vive voix, mais non sans amertume, que la France a été trompée par ses élèves, et Madagascar perdu par l'aveugle ambition de quelquesuns de ses enfants' (2012, p. 1637). Unsurprisingly, Cunard did not include this text in Negro.

Intellectuals in Madagascar were less prone to misunderstanding the true political colours of Rabearivelo. In February 1932, l'Aurore malgache, an anticolonial newspaper founded by the communist Paul Dussac, ran an investigation into the abduction of children in 
the Malagasy countryside and the authorities' inaction or even complicity. The author implicated Rabearivelo in this sordid affair, suggesting he had participated in a cover-up: 'Jean-Joseph Rabearivelo, journaliste, écrivain et poète de grande réputation, correspondant de quelques journaux français de répression des indigènes, c'est certainement un as!... Mais un as à la remorque de la grosse colonisation, c'est-à-dire participant à une œuvre contraire à l'émancipation de son pays. Il prête le concours de son talent à l'esclavagisme' (Aurore malgache, February 5, 1932). Such a remark pricked Rabearivelo's patriotic pride. In an unpublished fragment of his journal, he wrote: 'Moi, participer à l'émancipation de mon pays et prêter le concours de mon talent à l'esclavagisme ? Voici pourtant 12 ans que je sacrifie tout pour faire connaître Madagascar dans ce qu'il a de noble et de beau' (Fonds Rabearivelo, February 11, 1932).

Rabearivelo was therefore a Malagasy patriot who opposed the nascent communist movement in the colony. In Les Calepins bleus, he noted that if communism meant well, it should cease 'toute propaganda et rappele[r] tous ses lieutenants' (2012a, p. 205). Indeed, the journal expresses forcefully his anticommunism and affinities with the far right. In September 1933, he recounted attending a kermesse organised by the newspaper Le Colonial et Malagasy, of which he was literary editor :

On m'a donné un brassard tricolore vers 10h, puis l'on m'a aussitôt commis au contrôle. Quelle mine piteuse et embarrassée ! Un royaliste convaincu se voir obligé, pour faire plaisir à quelques vrais amis, de porter ostensiblement l'emblème républicain! On m'aurait ainsi photographié, et envoyé une épreuve à l'Action française... ça m’aurait bien embêté. $(2010,199)$

In January 1934, an exchange of articles in the Colonial et Malagasy and Le Madécasse, edited by the royalist Gaëtan Brugaët, concerning Rabearivelo's Maurrassism led him to explain his adherence to the ideas of l'Action francaise :

A moi qui ai donné mon adhésion à Maurras et à Daudet - la main dans celle du poète (Jean) Lebrau - au nom de l'Esprit (qui ignore ou dédaigne la Lettre) et du Sang (qui se moque de la Couleur). Une adhésion morale, en somme. Purement morale. Mais n'est-elle pas en de certaines circonstances, plus forte, plus agissante et plus précieuse que la... rogue des chiens de garde ? que le prosélytisme ? Tout cela qui, tout compte fait, n'est qu'un hommage inconsciemment rendu à la démocratie ? Fi de tout cela ! 
Une nation forte ne l'est que par ses aristos et jamais par son demos. L'Esprit, le Sang. Rien qu'eux. Mais seulement quand l'un et l'autre se valent. (2010, p. 344-345)

As France grappled with the political aftermath of the events of 6 February 1934, which saw the far right almost topple the Third Republic, Rabearivelo reasserted his creed: 'Assurée par le sang ou par l'effort, la royauté est toujours une chose éminemment respectable et immuablement grande à travers le monde. Tout comme l'intelligence' (2010, p. 482). His affinities with the virulently anti-German Maurras led to him having a less than positive view of Adolf Hitler once the Fuhrer took back the Saarland in early 1935 :

Or, je suis de ceux qui appellent de tous leurs vœux une guerre - avec ou sans merci, mais une guerre qui remettrait de l'ordre dans le monde affamé. Il est vrai qu'on ne sait jamais rien avec l'Allemagne. Et moins encore avec ce Juif antisémite d'Hitler qui lui chie dans la gueule et lui infuse, à la place du sang, du pipi au cœur. (2010, 739)

Another Maurrassian influence on Rabearivelo was admiration for the Provençal poet Frédéric Mistral. Mistral had played a key role in the félibrige movement, which championed local culture and language, and was considered by Maurras (1900) to be a counter-point to Jacobin centralism as well as the perceived cultural decadence of Paris. In 1935, Rabearivelo was visited by the editors of La Revue des Jeunes de Madagascar, who aimed to be as French as possible while remaining irreducibly Malagasy. In a lengthy interview, Rabearivelo cited Mistral as the inspiration for a view of Madagascar as one province among others in a greater France:

Croyez-m'en, l'harmonie de la Mère-Patrie ressort de sa diversité même : la personnalité du Breton ne se confond pas avec celle du Marseillais ; l'âme du Lillois diffère de celle de l'Auvergnat ; la langue de Paris ne ressemble guère au patois du Languedoc.... Tenez, puisque nous en sommes à cette dernière province, un mouvement dont peur s'inspirer le nôtre, c'est celui qu'a inauguré l'auteur de Mireille [Mistral]. Nous pouvons nous réclamer des félibres. Le félibrige, en effet, part d'une idée pareille à la nôtre : les poètes provençaux et provinciaux s'animent de ce sentiment que la portion de terre où la Providence a voulu les placer dans l'ordre de l'existence et de la nature, doit ajouter un éclat nouveau, singulier, à la gloire du Tout 
national par l'apport de ses richesses profondes, unes et uniques. (Revue des jeunes de Madagascar, 2, 1935, 26)

Yetanother reference was the historian and academician Jean Bainville, who had played a key role in the ideological development of Action française. The news of his death in early 1936, as the Front populaire closed in on power, brought an anguished re-assertion of faith :

Ainsi la France se dépeuple de ses plus pures gloires ; ainsi l'Intelligence, déjà bien «rare » comme herbes sur roche, dépérit, est décimée. Les rangs, comme on dit, des élus, se... Personnellement, j'ai ressenti et ressens encore ce deuil atroce parce que je suis Maurrassien et me sais et m'aime à dire un sujet du Roi exilé. Et parce que le défunt compta précisément parmi les piliers de notre parti. $(2010,1001)$

Since the twenties, Rabearivelo had been corresponding regularly with luminaries of Action francaise, notably the novelist Pierre Benoit and the poet marquis Xavier Magallon d'Argens, as well as being part of a coterie of royalists in the colony itself. Eventually this young lettré indigène would figure in the pages of 'l'organe du nationalisme intégral'. Certainly, the French empire had occupied a marginal place in the ideas of Charles Maurras and his followers: their main focus was the faults and crimes of republic and revolution and the nefarious activities of jews, communists, freemasons and other manifestations of l'antiFrance. If there was a foreign policy obsession, it was the German threat: Maurras's most important work on geopolitics was Kiel-Tanger. However, in the mid-thirties, L'Action française began to be more interested in the state of the colonies and, in June 1935, created 'La Lettre de France à nos amis d'outre-mer'. This fortnightly supplement, which featured on its masthead the cathedral of Notre-Dame and a tropical coastline, appeared 'pour que les grandes provinces de notre Empire se sentent chaque jour mieux compromise et entendues par l'esprit et la volonté de tous' (Action française, June 17, 1935). The 'Lettre de France' praised the exploits of hommes d'action like Lyautey and Gallieni, rejected democracy and, as the reference to 'provinces' suggests, preferred association rather than assimilation of the colonised. For these reasons, Action française championed the British Empire's 'génie de la décentralisation'. For Jean Paillard, this empire was 'la plus extraordinaire réussite coloniale que le monde ait jamais connue'. The secret of British success was that, 'instigatrice des idées révolutionnaires, elle eut cependant la bonne fortune de ne point les subir'. As for 
republican France, 'toutes ces possessions tendent - souvent d'ailleurs contre le gré des autochtones - vers l'assimilation politique, administrative et douanière avec la métropole'. For Paillard, there was no doubt where the colonial future lay: 'Les démocrates, pour lesquels la cohésion politique ne peut ressortir que de l'uniformisation systématique, ne pourraient jamais comprendre l'exemple de l'Empire britannique. Mais il est mourant avant lui' (Action française, February 22, 1937).

Action française emphasised the royal roots of French colonial expansion and its very British approach to political representation: 'avec sagesse elle légua ses pouvoirs autant que pouvait se faire, à des Conseils souverains destines à jouer un rôle analogue à celui de nos anciens parlements... C'était le triomphe de la décentralisation' (Action française, August 9, 1937) In June 1936, as the victory of the Front populaire raised hopes of radical political and social reform in the colonies, Jean Paillard attacked democracy : 'Comment ce régime, qui ne repose que sur la division des Français, sur les luttes de classes, sur l'antagonisme des intérêts, pourrait-il réussir ce chef d'œuvre ?' The author contrasted such republican anarchy with the example of the French Antilles 'qui, grâce à la Monarchie française, jouissaient d'un développement social exceptionnel' (Action française, September 14, 1936).

As for Madagascar, it was 'une colonie de première classe'. In their 'promenades', Marius and Ary Leblond, a couple of Greek brothers from La Réunion, observed '1'harmonie qui se réalise là avec une beauté suprême, de la somptuosité de la Nature en cette Australie africaine et de la majesté de l'Histoire de France'. The Leblonds therefore emphasised the longevity of French ties with la Grande Ile, which went way beyond 1789 : 'de Flacourt à Gallieni et Lyautey s'évoquent trois siècles d'intrépidité, d'épreuves, d'expérience, de persévérance, au sein de cette île dauphine que Richelieu et Colbert ont vouée à notre patrie avec la divination non seulement de ses richesses, mais de la grandeur exemplaire de la mission que nous avons à y accomplir'. The Leblonds also expressed their respect for Madagascar's defeated royalty : 'Le Hova est intelligent, souple, ingénieux, avide d'instruction vaniteuse et de degrés de noblesse qu'il appelle des honneurs : les autres peuples, négroïdes, le craignent et détestent' (Action française, December 16, 1935).

On 6 April 1936, the Hovas' finest literary son and member of Action française appeared for the first time in Maurras's journal. It was on the occasion of the performance of Rabearivelo's Malagasy pageant, Iamaitsoanala (La Fille d'Oiseau), on a théâtre de verdure in Antananarivo in front of 4000 spectators, including the Governor General himself, Léon Cayla. This indigenous work, created to mark la journée Lyautey and the opening of the new Hôtel de Ville, was 'une manière d'apostolat, dévoué à la mission passionnante de révéler 
aux profanes le vieil art lyrique malgache' (Action française, April 6, 1936). In November of that year, Action française carried an article in praise of Rabearivelo's poetry, celebrating its affinities with a famous victim of revolutionary terror: 'leur forme très pure, très harmonieuse, très classique, qui s'apporte étroitement à celle de cet André Chenier'. Such verse expressed a veritable association of French and indigenous cultures :

Pour nous, Français de la Métropole, c'est particulièrement émouvant que ce fils de l'Emyrne soit français de cœur et d'esprit, au point d'avoir fait sienne notre culture et de choisir notre langue pour exprimer son attachement à la patrie de ses ancêtres, à ses beautés, à ses traditions. Cette parfaite pénétration des cœurs et des esprits est le but suprême de la colonisation française. Les élites indigènes de la qualité de Jean Joseph Rabearivelo sont sa plus grande joie, sa plus légitime fierté.

The two poems selected, 'Regrets d'Iarive' and 'Autres regrets,' by their very titles, expressed a sense of loss at a time when the Front populaire threatened the old order, civil war raged in Spain, and Charles Maurras himself was in prison for incitement to murder. The Franco-Malagasy verse conveyed post-revolutionary melancholy:

Que de fois ton ombre entre toutes aimée,

M’y frôle aussi, Chénier. Que de fois ton printemps,

Infortuné comme l'Emyrne décimée,

M’y tresse plus de fleurs et de fruits éclatants. (Action française, November 2, 1936)

In Madagascar, the victory of the Front populaire raised hopes and caused dismay. The proposed reforms in the colony, which included a modest extension of the franchise and the abolition of forced labour, were modest, but radical enough to attract the ire of colons and their indigenous allies. In the form of l'Union franco-malgache and veterans' associations, opponents organised to counter the Front populaire and the communists and nationalists grouped around Paul Dussac and Le Prolétariat malgache. The public flying of the red flag and singing of the Internationale became the occasion for brawls and intervention by the authorities. In Les Calepins bleus, Rabearivelo chose the tricolour against the red threat:

Pour aujourd'hui, cette navrante constatation : la politique est introduite à Madagascar depuis juillet. Que sera demain, maintenant? Le sang ne va-t-il pas bientôt tacher nos 
pavés ? Moi, en bon Action Française, je ferai mon devoir - à droite - pour défendre, hélas !, le pavillon de la Gueuse qui, présentement, représente la France. Contre les Métèques. (2010, 1035)

Rabearivelo publicly associated himself with L'Union franco-malgache, signing a short article in Malagasy for the first issue of its journal. This public opposition to the Front populaire led to threats against him and his friend and fellow journalist Victor Malvoisin :

Nous étions tous deux, depuis près de deux mois, menacés de mort par les séides du Front Populaire local. Nous l'étions, ce jour-là, plus que jamais... Surtout que notre conférence à Excelsior - où devait se rendre, pour nous contredire, toute une meute le Gouvernement Général l'avait interdite. Comme, d'ailleurs, dorénavant, toute réunion publique. Or, nous circulions librement, avec la fierté, et non l'orgueil, d'avoir triomphé - nous qui étions désignés pour la mort ! $(2010,1035)$

His 'anti-political' political intervention also put considerable strain on his family :

J'ai prêché le calme. J'ai dit aussi que la Politique des partis doit être bannie de Madagascar. Et l'on m'en veut au point de me menacer de mort. Pire : moi et ma femme, et mes enfants - ceci, du moins, m'a été raconté au milieu d'abondante larmes, ce matin, par Mère. Etaient présents, avaient été convoqués tout exprès pour, Ramily et mon beau-père. J'ai répondu presque grossièrement - le Dieu de ma mère m'en pardonne ! Et l'on s'est quitté en « pure perte » - on voulait me faire renoncer à ma Politique. Bon Dieu ! parce que je dis que la Politique des partis sème la discorde et les plus fratricides luttes, l'on en veut maintenant à ma petite famille - moi compris ! Alors ! allez-y, Messieurs mes compatriotes ! Que je sois la première victime de ladite Politique - je m'en moque dès maintenant ! $(2010,1036)$

On October 7 1936, in Le Madécasse, Rabearivelo made his last political intervention, as part of the journal's 'grande consultation sur les aspirations des indigènes vues par les Malgaches'. Rabearivelo was keen to emphasise his credentials as a precocious critic of colonial policy in Madagascar. As early as 1923, he and his Malagasy colleagues had demanded 'l'élargissment de la naturalisation et une refonte de l'indigénat tendant vers son abolition. Nous combattions l'institution du SMOTIG. Enfin, nous réclamions un refonte de 
la justice d'exception'. This had been a time of missed opportunities : ' $\mathrm{Si}$, dès ce temps, l'Administration nous avait attentivement écoutés et qu'elle ne se bornât pas à quelques réformes anodines et, par trop simplistes, il ne resterait plus grand-chose à demander à l'heure où nous sommes'. Rabearivelo therefore rejected accusations from the left of being a stooge for colonialism :

Contrairement à ce que disent certains aujourd'hui jusque dans des réunions soi-disant contradictoires, les traîtres à leur patrie ne sont pas tout à fait du côté que l'on pense. Je ne vise personne en particulier, mais certains sont politiciens depuis hier : gens qui, la plupart du temps, n'ont rien fait de leur vie ; ils sont de bonnes raisons sans doute à s'agiter tout à coup. Résultat : l'introduction d'une chose néfaste pour la Colonie : la politique de partis.

Politics, he continued, 'est un vice, comme l'alcool ou les stupéfiants. S'il plaît à certains d'avoir des vices, qu'ils aient au moins la pudeur de ne pas les communiquer aux autres'. At the same time Rabearivelo claimed that he was not attacking any political party in particular : 'Ralaimango, ce super-chauvin, pour moi, reste un homme essentiellement honnête... J'ai de nombreux amis à Paris dans tous les partis : le grand Barbusse, avec qui j'ai correspondu huit ans durant'. He reminded readers that he had contributed to Nancy Cunard's Negro anthology, 'livre nettement communiste'.

That said, Rabearivelo was moderate in his criticisms and proposals. Concerning naturalisation, 'Je suis bien fier de rester tel que Dieu m'a fait et de garder le peu de chose racial qu'il m'est donné d'avoir... Pas de naturalisation massive, qui ne plairait pas à tout le monde. A moins de nous forcer la main, mais la France, après avoir déjà employé les armes, n'est pas venue ici, que je sache, pour faire ça'. Given the writer's run-ins with the tax man, it was no surprise that he attacked a tax regime which meant the natives paid from the age of 16 rather than 21 for French citizens. For Rabearivelo there would always be 'deux statuts et deux justices'. As for education, it should serve 'surtout à donner à nos enfants le moyen de devenir des hommes. Des hommes qui n'aient pas honte de revenir à la terre.... Les nourritures spirituelles ne sont, à mon avis, qu'une satisfaction personnelle'. He was, however, positive about some social reforms introduced by the Front populaire : 'Pour ce qui est de la semaine de 40 heures et des congés payés, il n'est que de les appliquer effectivement et strictement... Il est vraiment urgent d'améliorer la situation matérielle des ouvriers'. 
But unlike his nationalist and communist adversaries, Rabearivelo could not envisage any quick, radical transformation in relations between coloniser and colonised: 'la Fraternité n'est pas encore faite pour les générations que nous sommes. Il y a manque de contact et de confiance mutuelle. La Fraternité est faite pour nos enfants, et encore, pour les grandes cités seulement, à mon avis. Car là nos enfants, tous nés ici, auront grandi ensemble'. His one proposal for political reform was the creation of 'un conseil permanent comprenant avant tout des gens capables de donner un avis libre et connaissant bien les pays et les hommes' ( $L e$ Madécasse, October 6, 1936).

This intervention was reproduced at length in Action francaise under the title 'Un Malgache parle'. That said, it cut out the conciliatory references to Ralamaingo and Barbusse, as well as the positive remarks about paid holidays and a reduction in the working week. What was retained for publication was the rejection of universal naturalisation, the assertion that education of the natives should be primarily vocational, and the belief in association rather than some republican governance underpinned by citizenship (Action française, December 14, 1936).

As for reaction in Madagascar to Rabearivelo's article, he noted in his journal that, if some had attacked it, he had also received phone calls from 'trois personnes différentes toutes, hautes personnalités de la Colonie - me congratulant et, en même temps, m'assurant que mon programme sera en grande partie, sinon entièrement, retenu par le Gouvernement de la Colonie'. However, 'vinrent par là-dessus des... crustacés. M’enjoignirent dans les larmes de renoncer à toute action politique, parce que, pour la semaine prochaine, une journée rouge serait préparée et qu'après Mgr Fourcadier et les missionnaires protestants Mondain et Beigbeider, je figurerais en tête d'une liste de types à zigouiller' (2010, 1044). It was in this heated atmosphere that Rabearivelo penned a letter to Le Madécasse in which he compared himself to Socrates as well as a knight who vainly fought Don Quixote and announced his withdrawal from all political debate :'A partir d'aujourd'hui donc, « je reprends ma liberté vis-à-vis des hommes »,et ne m'occuperai plus, comme la cigale, qu'à chanter' (2010, 11451146).

In Les Calepins bleus, Rabearivelo did not, however, abandon all interest in events. The poisonous fruit of 'politics' seemed to manifest itself in nationalist demonstrations and strikes. He asked: 'Est-ce la fin de la race blanche ? Tout me porte à le croire, et, tout mélanien que je suis, à le regretter amèrement. Pourquoi ? - Je suis, certes, Scythe par filiation - mais par éducation, par culture...' $(2010,1049)$. He was glad to see the first performance in Madagascar, organised by young Malagasy intellectuals including Jacques 
Rabemananjara, of Corneille's royalist play Horace: 'J'ai, il est vrai, soufflé à Mme Quérillac pour l'Action française que je représente ici, et qui a trouvé beaucoup d'importance à la nouvelle' $(2010,1050)$. Events in Spain - whose language and culture Rabearivelo was also deeply attached to - gave some grounds for hope : 'Dès que l'armée nationaliste aura franchi le seuil de Madrid, je perpètre [sic] d'envoyer au Général Franco le câble suivant : Hurrá para salvador España inmortal y Europa tambien contra enemigo mundo entero Rabearivelo malgacho ! [Hourra au sauveur de l'Espagne immortelle.et aussi de l'Europe contre l'ennemi monde entier ! Rabearivelo, Malgache]' (2010, 1051). On November 9 1936, Rabearivelo received from Mme Quérillac a letter that could only be considered the sign of consecration for a young member of Action française :

Cette grande dame française avait reçu de Jean Tenant mes poèmes parus dans les Amitiés. Elle les avait lus et aimés. Elle les avait montrés à Louis Vincent qui avait immédiatement décidé de les faire lire à Maurras. Et celui-ci les avait aimés à son tour ! Quel plus grand honneur pour l'enfant que je suis ! Un autre petit détail qui m'a touché autant que cette... tuile dorée : en PS écrit à $11 \mathrm{~h}$ du soir, ma bonne correspondante me fait entendre que notre Maître suprême m'a lu le jour même de son arrestation (le 29 octobre, vers 17 heures). Et il est maintenant à la Santé - alors que d'autres que lui devraient y être ! Mais l'Intelligence française est en vacances, l'homme de la rue étant roi depuis mai 36... (2010, 1056)

This aristocratic disdain for 'la foule' comes through clearly in the last publication of his lifetime, Tananarive, ses quartiers, ses rues, written with Eugène Baudin. Using erudition and humour, the authors explained the place names of the old city, referring to a royal past while giving virtually no mention of ordinary people, unless it was disparaging. The work ended with a list of the new names of the Malagasy capital's streets, which, from place Colbert to avenue Lyautey, bore the heavy imprint of French colonial rule. There was mention of the inauguration of the Léon Cayla tunnel, with these words of praise for the Governor General: 'C'est sous son impulsion que Madagascar a été sillonné de routes, c'est à lui que sont dus les embellissements et la complète transformation de la Capitale - sans compter les œuvres d'assistance sociale, l'aviation, etc'. $(1937,88)$

In February 1937, Action française devoted a long article to Rabearivelo, under the title 'Fleurs malgaches de la colonisation'. For Claude Queveney, Rabearivelo expressed the inherently poetic nature of the Malagasies : 'c'est toujours le même sentiment poignant de la 
mort, du culte des ancêtres et de leurs tombeaux qui l'inspire'. The essential characteristic of Rabearivelo’s work was ‘la gravité mélancolique avec laquelle il célèbre sa sylve natale, l'atmosphère ardente de l'Emyrne ou les ancêtres disparus de sa race splendide'. His collection Chants pour Abéone, inspired by a dual attraction towards land and sea, pointed to an internal struggle between a westernised intellectual and his native influences. Despite his genius, Queveney argued, Rabearivelo's identity and status remained problematic, and he placed the blame for this on France:

Le talent de Rabearivelo ne lui vaut encore ni richesse ni gloire. La Monarchie eût aidé à l'épanouissement d'un tel talent. Mais l'administration républicaine s'en est désintéressé ou presque. Elle n'a même pas saisi l'occasion de l'Exposition de Vincennes, pour appeler Rabearivelo à Paris, où un contact direct avec les poètes métropolitains lui eût été favorable. La politique, le favoritisme, l'envie ont-ils, comme on l'a voulu dire, joué, une fois de plus, contre le mérite réel ? Quoi qu'il en soit, s'il n'est pas un Français de la métropole qui puisse rester insensible à ce génie très différent du nôtre, mais si vraiment fraternel qu'il a choisi nos mots, pour exprimer son attachement à la patrie de ses ancêtres, à ses beautés, à ses traditions. C'est là le miracle de la vraie colonisation qui n'est pas l'assimilation stupide et massive, mais la pénétration des âmes et des cœurs. (Action française, February 8, 1937)

\section{Death of a Malagasy Mistral}

Queveney's text virtually speaks of Rabearivelo in the past tense. Indeed, Les Calepins bleus indicate a personal crisis that would soon prove terminal. Francis Koerner makes the reasonable observation that 'l'itinéraire politique de Rabearivelo est très tortueux et il se pourrait qu'il ait eu une influence sur la destinée tragique du poète' $(1994,316)$. However, a cocktail of factors contributed to the poet's malaise. Despite the help of influential friends, Rabearivelo was unable to obtain a post in the colonial administration, ostensibly on the grounds that he lacked academic qualifications. Despite being a member of the commission preparing Madagascar's contribution to the Exposition universelle, it seems that Léon Cayla, who had an ambivalent relationship with the poet, decided not to include him in the official delegation. Added to this were the effects of systematic alcohol and drug abuse, the haunting 
memory of his dead daughter Voahangy, and a longstanding obsession with the violent deaths of writers. On 22 June 1937, Rabearivelo killed himself with cyanide.

The author recounted his last moments in Les Calepins bleus and wrote farewell letters to friends, including Robert Boudry, whom he appointed executor of his estate. Also among the addressees was Action française, which published this farewell to 'son maitre aimé et vénéré, Charles Maurras':

Mes chers amis,

C'est vraiment plus fort que moi, j'abandonne ayant trop longtemps en vain lutté.

Cette lettre, si elle vous parvient, c'est donc mon faire-part mortuaire. Il n'y a aucune raison d'en pleurer, d'en être triste, et c'est avec sérénité que vais là-bas dans le Néant, dans la solitude. Adieu. Dites au Maître toute l'humble amitié que lui aura vouée, toute sa vie, celui qui signe Jean Joseph Rabearivelo.

Claude Queveney did not hesitate to give a political significance to this suicide. For him, Rabearivelo's poetry expressed 'l'harmonie des collines imériniennes', but 'il était Français aussi et d'autant plus profondément qu'il était maurrassien. Il chantait avec amour sa terre natale, mais aimant en même temps la France colonisatrice ; et c'est dans la doctrine maurrassienne qu'il puisait des raisons de ne pas désespérer de cette lointaine patrie'. And yet, France had forgotten him : 'il est mort, faute d'avoir obtenu la modeste situation de bibliothécaire qu'il avait demandé'. To this was added his exclusion from the Malagasy delegation to the Exposition universelle: 'Tout ce qui était venu d'Occident à Rabearivelo lui a donc fait défaut... Une sage tutelle - celle de la Monarchie - eût aide ce talent à s'épanouir et ce poète à vivre. Avant de songer à créer une élite indigène elle lui aurait préparé les cadres indispensables... de tels exemples doivent servir de leçons' (Action française, September 20, 1937). The major lesson to be drawn from the death of this Malagasy Mistral was that association was more effective and desirable than assimilation.

It was in such a spirit that, a month later, Queveney praised another young poet of the colonies, Léopold Senghor, for his speech on indigenous education to the Chamber of Commerce in Dakar. West Africa's first agrégé, Senghor represented 'le type de ces élites indigènes dont la France a le droit d'être fière'. Queveney quoted him approvingly : 'L'Europe ne doit pas assimiler l'Afrique ; mais si l'Afrique doit assimiler l'Europe, elle doit cependant rester elle-même'. Senghor's preference for a bilingual and even 'bicéphale' 
culture, and his emphasis on vocational training for the natives, seemed to correspond to the Action française line :

Comme nous sommes loin, ici, des intellectuels indigènes de première manière, lesquels, dans leur zèle de néophytes, voulaient, sous prétexte de progrès, faire table rase du passé. Il est réconfortant de constater que les véritables lettrés indigènes ont compris l'absurdité de cette thèse et sont d'accord avec nous pour s'opposer à ce qu'on peuple la France d'outre-mer de déracinés. (Action française, October 4, 1937)

Indeed, Martin Steins points out ideological affinities which sit uncomfortably with any attempt to present négritude as fundamentally of the left :

Du côté de l'Action française, on était prêt, visiblement, à reconnaître l'existence de cultures indigènes, nées de traditions et de races qui demeuraient très éloignées de tout ce qui avait fait la France. Mieux, on y souhaitait même que ces différences fussent maintenues, car elles étaient le produit du « pays réel », si cher à Maurras, c'est-à-dire le produit d'un climat, d'un sol, d'une histoire et d'une ethnie, dont les effets mélangés représentaient le réservoir de toute créativité culturelle. $(1981,903)$

Action française could therefore be an ideological recourse for young colonial intellectuals unconvinced by republican assimilationism. Senghor's outspoken support for the vocational and Africanised education offered by the Ecole Rurale Populaire could be construed as reactionary and contrary to the assimilationist aspirations of an emerging indigenous bourgeoisie. It also echoed the ideas expounded by Rabearivelo in his last political intervention, although there is no trace of any correspondence between the two men. On the other hand, the royalist Queveney did not mention Senghor's call for the extension of French citizenship to Africans, regardless of cultural difference. What's more, the Senegalese intellectual's belief in 'active assimilation' of western culture and technology had a forwardlooking vigour that contrasted with both Maurrassian paternalism and Rabearivelo's crepuscular vision of his personal and political situation. Once Senghor's project was thwarted by metropolitan France, it would transform into a more militant African socialism.

Rabearivelo soon disappeared from the pages of Action francaise. What's more, the 'Lettre de France' vanished after the declaration of war in September 1939: the ancestral threat of Germany eclipsed other preoccupations. However, in Madagascar, an intense 
posthumous existence was beginning for the Franco-Malagasy poet. In January 1939, the very official Revue de Madagascar could be seen to make amends for his alleged mistreatment by publishing, at Rabearivelo's request, 'Vieilles chansons des pays d'Imerina'. He also had his place in the Révolution Nationale which Charles Maurras would fatally rally to. In Vichy in the Tropics, Eric Jennings has shown how Madagascar's largely antiassimilationist, antirepublican, and Anglophobic colonizers were delighted in the news that Léon Cayla had been nominated by Vichy to run the island: 'In the span of three months, the French in Madagascar had thus been won over to the National Revolution, which, local administrators soon concurred, suited and simplified the colonial mission' $(2001,37)$. On the Red Island, Cayla led resistance to 'decadence' through sports for youth and other cultural activities. Assimilation was repudiated and native education overhauled to emphasise vocational training. Pétain was reinvented as a successor of the king Andrianampoinimerina, while statute labour was used freely again by colonists now facing the consequences of an Allied blockade. Culturally, Rabearivelo had his place: in the one issue of the revived Revue de Madagascar, published in January 1941, an anthology of Pétain's speeches and telegrams sat alongside poetry by Rabearivelo and some of his Malagasy disciples. This National Revolution was, however, doomed, with the British invading the island in September 1942, which prompted Charles Maurras to abandon his previous admiration of British imperialism : 'Les actes de félonie que l'Angleterre continue de multiplier contre nous rendent singulièrement ardus et, en tout cas, lointain tout avenir d'entente entre les Anglas et tout Français digne de ce nom' (Action française, September 28, 1942). Action francaise would emerge from the Second World War compromised by its association with Vichy, and its 'Maître' spend his last years in prison (2004).

\section{Conclusion}

Ten years after his suicide, Rabearivelo's country was rocked by its most important uprising against French rule, with the number of victims on both sides estimated in the tens of thousands. As clashes were reported near the home village where the poet was buried, the resolutely colonialist Journal de Madagascar invoked his memory:

Puisse sa tombe, que n'indique dans la campagne de l'Imerina ni une inscription, ni un signe religieux, et que n'ombrage qu'un simple goyavier, être légère à ce poète de la solitude et du renoncement. Des hommes se battent aujourd'hui non loin d'elle qui 
devraient comprendre par son exemple tragique que la France et Madagascar peuvent vivre côte à côte. (Journal de Madagascar, July 5-6, 1947)

However, as repression abated and independence appeared increasingly inevitable, Rabearivelo and his violent death were inscribed in a new anti-colonialist narrative. Robert Boudry had been dismissed from the colonial administration for his pro-Malagasy nationalist leanings. Back in France, he became a regular contributor to the communist journal $\mathrm{La}$ Pensée. In 1958, shortly before his own death, Boudry wrote a book in homage to his late friend, in which declared: 'Son suicide est à la fois la condamnation d'un régime qui est la négation de la culture, et un avertissement. Incompris dans le présent il s'adresse à l'avenir' $(1958,84)$. There was no mention of Rabearivelo's pro-Maurras convictions. Instead, he was now a precursor of anti-colonial intellectuals like Senghor who stood for négritude, African socialism and even marxism. For Senghor himself, with this suicide, 'le prince des poètes malgaches' 'se vengeait ... des philistins et de l'Administration colonialiste, s'imposant du même coup à l'attention de ses pairs, les princes de l'art et de la poésie' $(1992,180)$. Thus, the 'future' buried the traditionalism that had made pre-war nationalisme intégral - and a more political form of 'princeliness' - so attractive. After Madagascar became independent, in 1960, the new regime tried to appropriate Rabearivelo as a symbol of Franco-Malagasy friendship, embellishing his family tomb at Ambatofotsy with a sculpture that would soon start to crumble, while intellectuals still argued over the sense of his suicide and the relative merits of his work in French and Malagasy. Despite attempts at ideological 'flattening', Rabearivelo was, and remains, a complex and tragic colonial intellectual whose maurrassisme can be seen as one attempt at resolving intolerable contradictions.

\section{References}

Baudin, Eugène and Rabearivelo, Jean-Joseph. 1937a. Tananarive. Ses quartiers, ses rues. Antanananarivo : Imprimerie d'Imerina.

Boudry, Robert. 1958. Jean-Joseph Rabearivelo et la mort. Paris : Présence africaine. Fremigacci, Jean. 2014. Etat, économie et société coloniale à Madagascar. Paris : Karthala. Jennings, Eric. 2001. Vichy in the Tropics: Pétain's National Revolution in Madagascar, Guadeloupe and Indochina, 1940-1944. Stanford: Stanford University Press.

Koerner, Francis. 1994. Madagascar. Colonisation française et nationalisme malgache. Paris : L'Harmattan. 
Maurras, Charles. 1937b. Mes idées politiques. Paris : Fayard.

Maurras, Charles. 1900. Mistral suivi d'Excursion en Italie. Paris : Aubier.

Prévotat, Jacques. 2004. L'Action française. Paris : Que sais-je ?.

Rabearivelo, Jean-Joseph. 2010. Euvres complètes, Tome I. Paris : CNRS Editions.

Rabearivelo, Jean-Joseph. 2012. Euvres complètes, Tome II. Paris : CNRS Editions.

Senghor, Léopold Sédar. 1992. Anthologie de la nouvelle poésie nègre et malgache de langue française. Paris : Presses universitaires de France.

Steins, Martin. 1981. 'Les antécédents et la genèse de la négritude senghorienne', Thèse de doctorat d'état, Université de Paris III - Sorbonne Nouvelle. 